\title{
Tribute to our Father, Evandro de Oliveira
}

\author{
Romina Leite da Costa de Oliveira ${ }^{1}$ Sabrina Leite da Costa de Oliveira ${ }^{1}$ \\ 1 Sociedade Brasileira de Neurocirurgia
}

Arq Bras Neurocir 2021;40(1):2-3.

Evandro de Oliveira was a great father. He lived his life based on two pillars: family (-Figs. 1, 2, 3 and 4) and work. He always succeeded in finding a balance between the two. He put in place what he taught us to: living with love; that would be the only way to achieve excellence in anything we do. And the outcome would be having more chances to experience the path of happiness.

The giant of his specialty - so tough, so demanding, so determined, so strong-willed - was a tolerant, generous, sensitive, sweet, loving, and warm father to his daughters. He was the inspiration of our lives!

Although he was the great master of Neurosurgery, so absorbed in his art, he found time and space throughout his life to be a wonderful father to Romina and Sabrina. Always close and present, he was ready to help solve any trouble we

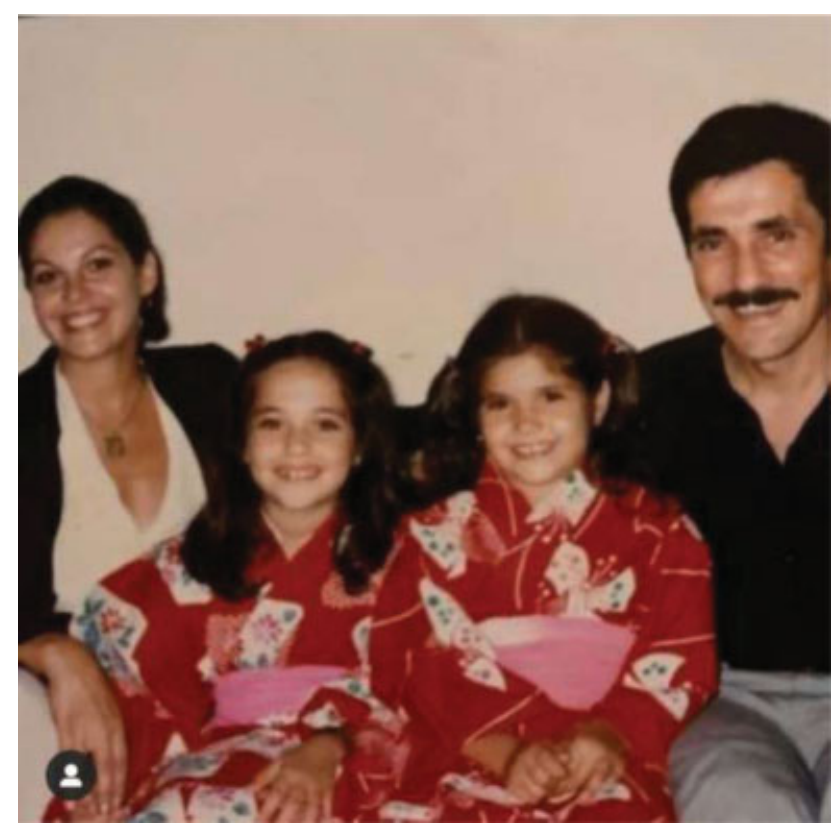

Fig. 1 Evandro and his family: Marina, Romina e Sabrina, Gainsville, Florida 1981.

Address for correspondence Romina Leite da Costa de Oliveira, Sociedade Brasileira de

DOI https://doi.org/

Neurocirurgia

(e-mail: sergio.curcio@gmail.com).

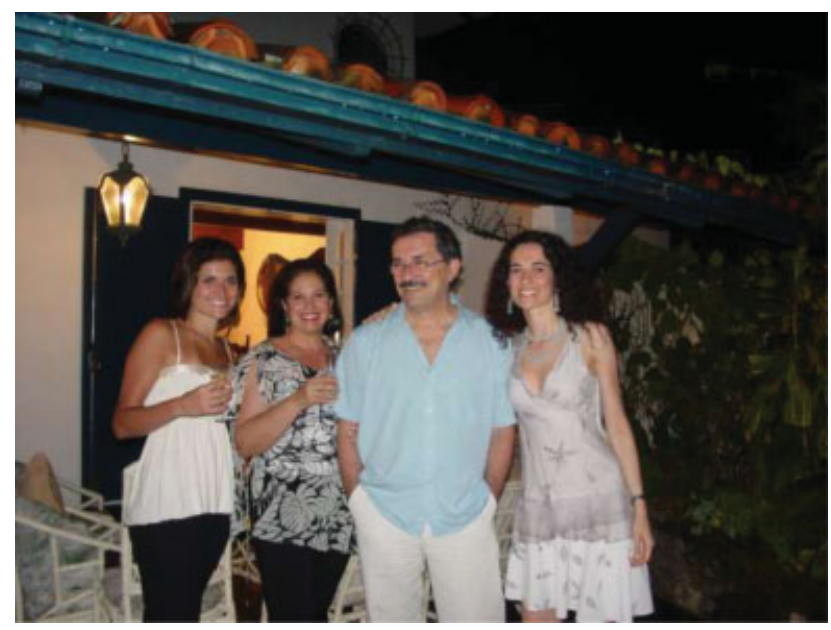

Fig. 2 Evandro during New Year Celebration party with his family in Florianopolis, the city in which he was born (2006).

faced. He always got ahead of us and presented solutions to any problem he thought could harm or hinder us.

Committed to doing his best, to giving his best, to being his best, he wanted to see us fulfilled and happy the way we

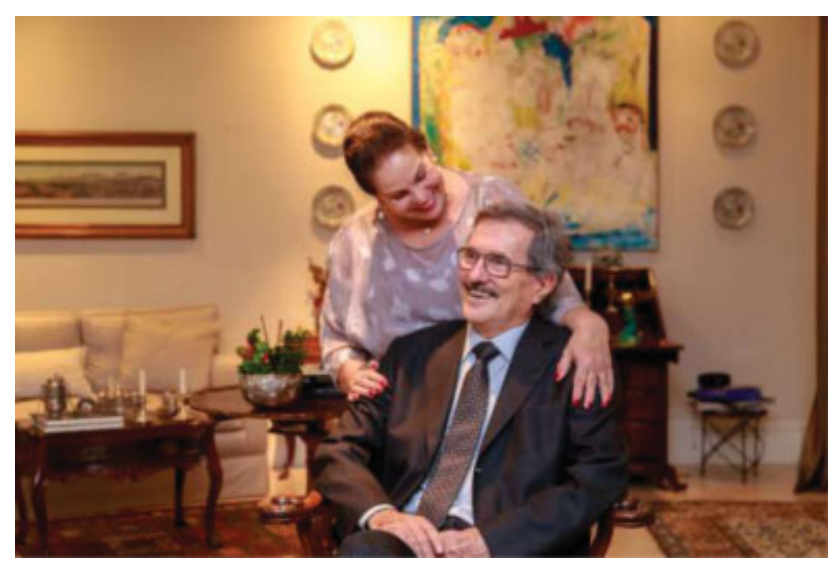

Fig. 3 Evandro and Marina in his 73th anniversary. Sao Paulo.

(c) 2021. Sociedade Brasileira de Neurocirurgia. All rights reserved. This is an open access article published by Thieme under the terms of the Creative Commons Attribution-NonDerivative-NonCommercial-License, permitting copying and reproduction so long as the original work is given appropriate credit. Contents may not be used for commercial purposes, or adapted, remixed, transformed or built upon. (https://creativecommons.org/ licenses/by-nc-nd/4.0/)

Thieme Revinter Publicações Ltda., Rua do Matoso 170, Rio de Janeiro, RJ, CEP 20270-135, Brazil 


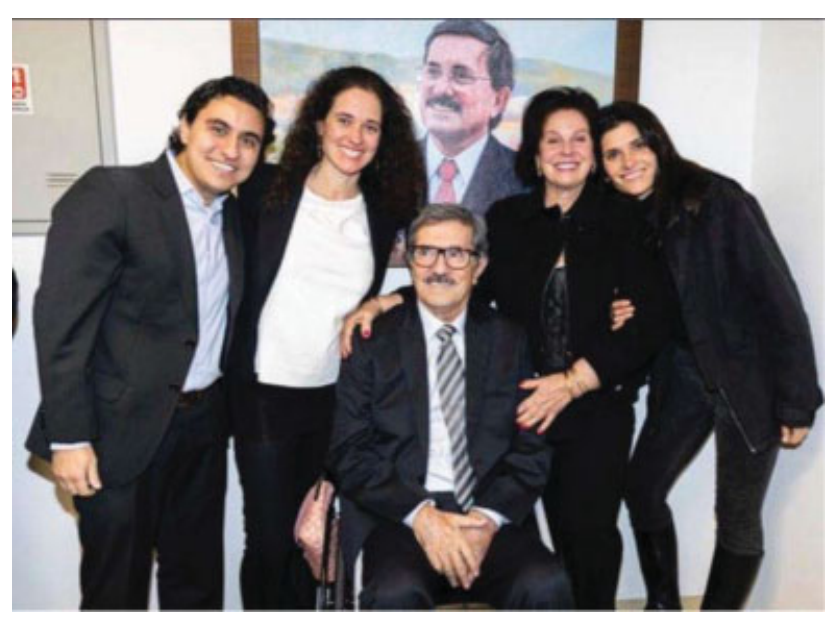

Fig. 4 Evandro in his microsurgical laboratory at Hospital Beneficencia Portuguesa de São Paulo (2019). From left to right: Sergio Curcio (his son-in-law), Romina, Marina and Sabrina.

chose to be and live. Evandro was even greater as a father than as a neurosurgeon. He achieved the purpose he established for himself when he was a boy: to be the best father to his kids. He gave himself to us with unconditional love. He was a friend, an accomplice, and a partner. Always attentive and open to the choices we made, he allowed us to be free. His only wish was that we were happy. No matter when or how, he accepted us even if he thought we were wrong. He was torn up just imagining that we could be suffering for any reason.

In his likewise grand way of demonstrating his love and affection, he was always with us. And this connection ensured that we have never felt in our lives his absence, as it would be expected considering his intense dedication to medicine.

He took pleasure in always giving us the best of everything. He knew us as no one else did! He nourished us with love, care, and gifts; he filled our house with flowers, delicacies, and above all, with his generosity to welcome and gather people.

While he loved operating and traveling the world sharing and exchanging experiences at uncountable medical conferences and symposia, he was happy to come home.

When he traveled alone for work, he limited himself to completing his professional commitments with excellence, and whenever he had a break, however small, he managed to fill his suitcases with gifts, showing us what we already knew: he was always connected to us. He always preferred to travel, however, with our mother by his side. Only then was he able to turn off the physician to be simply Marina's Evandro. Only with his wife beside him he fully enjoyed the places he traveled to.

When in São Paulo, he used to spent time just relaxing with us. Resting in a chair on the patio and smoking a cigar, was enough to recharge him.

When in Florianopolis, he enjoyed looking at the ocean as far as his eyes could see. "Ingleses beach" was a place he liked so much. He relaxed there enjoying a typical barbecue after a sea bath, savoring a dozen fresh oysters, petting his dogs, laughing with old friends and local family, and above all, enjoying the company of his life partner, our mother, Marina. He could spend months and months that way. And it was how he wished to live the last days of his life.

How privileged and lucky we are for having Evandro as our daddy.

How privileged and lucky our mom is for having Evandro as her husband.

Thank you for giving us life, dad!

We love you forever.

Conflict of Interest

None. 